\title{
ANALISIS KINERJA KEUANGAN PEMERINTAH KOTA LHOKSEUMAWE
}

\author{
Wahyuddin ${ }^{1}$, Nora Sugianal ${ }^{2}$ \\ ${ }^{1,2}$ Prodi Akuntansi Fakultas Ekonomi dan Bisnis Universitas Malikussaleh Lhokseumawe \\ wahyuddin@unimal.ac.id
}

\begin{abstract}
This study aims to analyze the financial performance of Lhokseumawe City using the Fiscal Decentralization Degree Ratio, Independence Ratio, PAD Effectiveness Ratio, Regional Financial Efficiency Ratio, and Harmony Ratio. The data used in this study are quantitative data, namely, Budget Realization Reports sourced from BPKD (Regional Financial Management Agency of Lhokseumawe City. Data collection uses documentation method. Data analysis method used is quantitative descriptive with the formula of Fiscal Decentralization Ratio, Independence Ratio, Ratio Effectiveness of PAD, Regional Financial Efficiency Ratio and Harmony Ratio The results of this study indicate that the financial performance of the government of Lhokseumawe City uses a Degree of Decentralization Ratio which can be categorized as very poor, because the average is $6.03 \%$, the Regional Financial Independence Ratio is still classified instructive relationship because the average magnitude of this ratio is $7.82 \%$, PAD Effectiveness Ratio of the financial performance of Lhokseumawe City is less effective because the average effectiveness is below 100\% which is $90.55 \%$, Regional Financial Efficiency Ratio can be said to be less efficient because the average of regional financial efficiency of Lhokseumawe City is $96.59 \%$, the Harmony Ratio is known that the average regional operating expenditure is still very high at $57.84 \%$ compared to the average capital expenditure of $23.29 \%$. So, it can be said that the Regional Government is still not good at managing the government.
\end{abstract}

Keywords: Local Government Financial Performance, Degree of Fiscal Decentralization Ratio, Regional Financial Independence Ratio, PAD Effectiveness Ratio, Regional Financial Efficiency Ratio, and Harmony Ratio.

\section{PENDAHULUAN}

Pelaksanaan otonomi daerah yang diatur dalam Undang-undang No. 32 Tahun 2004 tentang Pemerintahan Daerah dan Undang-undang No. 33 Tahun 2004 tentang Perimbangan Keuangan antara Pemerintah Pusat dan Daerah, memberikan kewenangan yang luas kepada pemerintah daerah baik itu kabupaten maupun Kota, untuk mengurus rumah tangganya sendiri baik dalam bidang pembangunan, pemerintahan, dan kemasyarakatan.

Pemerintahan Kota Lhokseumawe merupakan Kota hasil pemekaran dari Kabupaten Aceh Utara sejak tahun pertama dibentuknya Kota Lhokseumawe yaitu pada tahun 2011 sampai dengan saat ini, pertanggung jawaban atas pengelolaan keuangan daerah dilakukan sesuai dengan peraturan perundang- undangan tentang pengelolaan Keuangan Daerah.

Sesuai dengan Undang-undang Dasar Negara Republik Indonesia tahun 1945, pemerintah daerah berwenang untuk mengatur dan mengurus sendiri urusan pemerintahan menurut asas otonomi dan tugas pembantuan. Pemerintah Daerah adalah pelaksanaan fungsi-fungsi pemerintahan daerah yang dilakukan oleh lembaga pemerintahan daerah yaitu Pemerintah
Daerah dan Dewan Perwakilan Rakyat Daerah (Pemda dan DPRD).

Tujuan otonomi daerah ini tidak lain adalah untuk mewujudkan kesejahteraan masyarakat daerah yang dilakukan dengan cara meningkatkan kualitas pelayanan, pemberdayaan masyarakat, dan terbentuknya sarana dan prasarana di daerah yang layak. Di samping itu, pelaksanaan otonomi daerah juga dimaksudkan untuk mewujudkan pengelolaan sumber daya alam secara efektif serta memberikan kesempatan bagi warga daerah untuk berpartisipasi di dalam penyelenggaraan pemerintahan. Dengan diterapkannya otonomi daerah, diharapkan kualitas dan daya saing daerah otonom semakin meningkat dan juga dapat berdampak pada kemajuan dan kesejahteraan masyarakatnya.

Menurut Kamus Akuntansi Manajemen, Kinerja Keuangan Pemerintah Daerah adalah sebagai berikut : "Pengertian kinerja Keuangan pemerintah Daerah diartikan sebagai aktivitas terukur dari suatu entitas selama periode tertentu sebagai bagian dari ukuran keberhasilan pekerjaan. Pengukuran kinerja diartikan sebagai suatu sistem keuangan atau non keuangan dari suatu pekerjaan yang dilaksanakan atau hasil yang dicapai dari suatu aktivitas, suatu proses atau suatu unit organisasi”. Kinerja keuangan 
pemerintah daerah menjadi sorotan publik, hal ini mendukung dengan pernyataan Mardiasmo (2009:121) yang menyatakan bahwa kinerja pemerintahan merupakan suatu hal yang penting untuk menilai akuntanbilitas organisasi dan manajemen dalam menghasilkan pelayanan publik yang lebih baik. Informasi yang disajikan dalam pelaporan keuangan harus memenuhi karakteristik kualitatif sehingga dapat digunakan dalam pengambilan keputusan (Silky, 2012).

Dewasa ini, praktik akuntansi sektor publik yang dilakukan oleh lembaga- lembaga pemerintah banyak mendapat perhatian dibanding masa-masa sebelumnya. Terdapat tuntutan yang lebih besar dari masyarakat untuk dilaksanakannya transparansi dan akuntabilitas publik oleh lembaga-lembaga sektor publik (Mardiasmo, 2009:1). Dalam rangka melakukan upaya konkrit mewujudkan good governance, serta meningkatkan transparansi dan akuntabilitas pengelolaan keuangan pemerintah, maka baik pemerintah pusat maupun pemerintah daerah, wajib menyampaikan laporan pertanggungjawaban yang berupa laporan keuangan. Bentuk laporan pertanggungjawaban atas pengelolaan keuangan daerah selama satu tahun anggaran adalah dalam bentuk Laporan Keuangan Pemerintah Daerah (LKPD), yang terdiri dari Laporan Realisasi Anggaran, Neraca, Laporan Arus Kas, dan Catatan Atas Laporan Keuangan (Masdiantini dan Erawati, 2016).

Tuntutan pengukuran kinerja keuangan pemerintah daerah perlu dilakukan karena adanya fakta bahwa masih buruknya kinerja pemerintah daerah di indonesia yg dapat terlihat dengan adanya pernyataan Ketua Badan Pemeriksa Keuangan RI (BPK RI), Anwar Nasution (Antarnews.com, 2007), bahwa masih buruknya tranparansi dan akuntabilitas pemerintah daerah sehingga hal tersebut berdampak pada buruknya penilaian kinerja pemerintah daerah.

Berdasarkan Undang-Undang Republik Indonesia Nomor 33 Tahun 2004 tentang Perimbangan Keuangan antara Pemerintah Pusat dan Pemerintah Daerah, dana alokasi umum (DAU) adalah dana yang bersumber dari pendapatan Anggaran Pendapatan dan Belanja Negara (APBN) yang dialokasikan dengan tujuan pemerataan kemampuan keuangan antar daerah untuk mendanai kebutuhan daerah dalam rangka pelaksanaan desentralisasi. Dana alokasi umum (DAU) diberikan pemerintah pusat untuk membiayai kekurangan dari pemerintah daerah dalam memanfaatkan pendapatan asli daerah (PAD) nya. Penggunaan dana alokasi umum (DAU) diserahkan kepada pemerintah daerah sesuai dengan prioritas, kepentingan, dan kebutuhan daerah masing-masing yang bertujuan untuk 3 meningkatkan pelayanan publik dalam rangka melaksanakan otonomi daerah.

\section{TINJAUAN PUSTAKA}

Menurut Peraturan Pemerintah Republik Indonesia Nomor 58 Tahun 2005, tentang Pengelolaan Keuangan Daerah dalam ketentuan umumnya menyatakan bahwa keuangan daerah adalah semua hak dan kewajiban daerah dalam rangka penyelenggaraan pemerintah daerah yang dapat dinilai dengan uang termasuk didalamnya segala bentuk kekayaan daerah tersebut.

Menurut Kamus Akuntansi Manajemen, Kinerja Keuangan Pemerintah Daerah adalah sebagai berikut : "Pengertian kinerja Keuangan pemerintah Daerah diartikan sebagai aktivitas terukur dari suatu entitas selama periode ter sebagai bagian dari ukuran keberhasilan pekerjaan. Pengukuran kinerja diartikan sebagai suatu sistem keuangan atau non keuangan dari suatu pekerjaan yang dilaksanakan atau hasil yang dicapai dari suatu aktivitas, suatu proses atau suatu unit organisasi".

Kinerja Keuangan Pemerintah Daerah adalah keluaran/hasil dari kegiatan/program yang akan atau telah dicapai sehubungan dengan penggunaan anggaran daerah dengan kuantitas dan kualitas yang terukur, kemampuan daerah dapat diukur dengan menilai efisiensi atas pelayanan yang diberikan kepada masyarakat (Sumarjo, 2010). Organisasi sektor publik yang salah satunya pemerintah merupakan organisasi yang bertujuan memberikan pelayanan publik kepada masyarakat dengan sebaikbaiknya, misalnya dalam bidang pendidikan, kesehatan, keamanan, penegakan hukum, transportasi dan sebagainya. Pelayanan publik diberikan kepada masyarakat yang merupakan salah satu stakeholder organisasi sektor publik, oleh karena itu Pemerintah Daerah wajib menyampaikan laporan pertanggung jawaban kepada DPRD selaku wakil rakyat di pemerintahan. Dengan asumsi tersebut dapat dikatakan bahwa Pemerintah Daerah membutuhkan sistem pengukuran kinerja yang bertujuan untuk membantu manajer publik untuk menilai pencapaian suatu strategi melalui alat ukur finansial dan non finansial. Sistem pengukuran kinerja sendiri dapat dijadikan sebagai alat pengendalian organisasi. Kinerja yang baik bagi Pemerintah Daerah dicapai ketika administrasi dan penyediaan jasa oleh Pemerintah Daerah dilakukan pada tingkat yang ekonomis, efektif dan efisien (Adhiantoko, 2013).

Dalam rangka pelaksanaan kewenangan Pemerintah Daerah sebagaimana ditetapkan dalam Undang-Undang Nomor 32 Tahun 2004 tentang Pemerintah Daerah, yang diikuti dengan perimbangan keuangan antara Pemerintah Pusat dan Pemerintah Daerah sebagaimana diatur dalam Undang-Undang Nomor 33 Tahun 2004 timbul hak daerah yang dapat dinilai dengan uang sehingga perlu dikelola dalam suatu sistem pengelolaan keuangan daerah, dan dikeluarkan Peraturan Pemerintah Republik Indonesia nomor 58 tahun 2005 tentang Pengelolaan Keuangan Daerah. Pengelolaan daerah sebagaimana dimaksud merupakan sub sistem dari sistem pengelolaan keuangan negara dan merupakan elemen pokok dalam 
penyelenggaraan pemerintahan daerah. Pengelolaan tersebut juga ditunjang dengan keluarnya Peraturan Menteri Dalam Negeri nomor 13 tahun 2006 tentang Pedoman Pengelolaan Keuangan Daerah untuk lebih melengkapi sistem.

Pengukuran Kinerja Keuangan Pemerintah Daerah dilakukan untuk memenuhi 3 tujuan yaitu (Mardiasmo, 2002: 121):

a. Memperbaiki kinerja Pemerintah Daerah.

b. Membantu mengalokasikan sumber daya dan pembuatan keputusan.

c. Mewujudkan pertanggungjawaban publik dan memperbaiki komunikasi kelembagaan.

d. Rasio efisiensi adalah rasio yang menggambarkan perbandingan antara besarnya biaya yang dikeluarkan untuk memperoleh pendapatan dengan realisasi pendapatan yang diterima.

\section{Laporan Realisasi Anggran}

Laporan Realisasi Anggaran merupakan komponen penting yang mengundang perhatian publik. Disebabkan karena masyarakat sebagai pemberi dana publik melalui pajak daerah yang mereka bayarkan berkepentingan untuk mengetahui apakah dana tersebut telah digunakan dengan semestinya, efesien, efektif dan berorientasi pada kepentingan publik.

Laporan Realisasi Anggaran (LRA) yang dipublikasikan pemerintah daerah memberikan informasi yang sangat bermanfaat untuk menilai kinerja keuangan daerah. Jika dibandingkan dengan neraca, LRA menduduki prioritas yang lebih penting, dan LRA ini merupakan jenis laporan keuangan daerah yang dahulu dihasilkan sebelum membuat laporan neraca dan laporan arus kas. Anggaran dalam pemerintahan merupakan tulang punggung (backbone) penyelenggaraan pemerintahan. Anggaran memiliki peran penting sebagai alat stabilisasi, distribusi, alokasi sumber daya publik, perencanaan dan pengendalian organisasi serta penilaian kinerja. Oleh karena itu LRA menjadi salah satu laporan pertanggungjawaban keuangan daerah yang utama. Berdasarkan LRA tersebut pembaca laporan dapat membuat analisis kinerja laporan keuangan berupa analisis pendapatan, analisis belanja dan analisis pembiayaan

Tujuan dari laopran Realisasi Anggaran adalah sebagai berikut:

1. Menetapkan dasar-dasar penyajian laporan realisasi anggaran untuk pemerintah dalam rangka memenuhi tujuan akuntabili ${ }^{+}$ sebagaimana ditetapkan oleh peratur

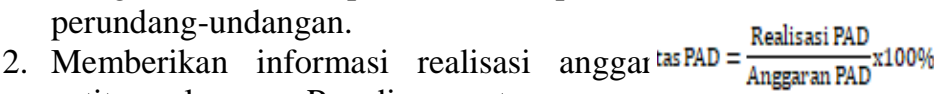

entitas pelaporan. Paradigma antara anggar. dan realisasinya menunjukkan tingkat ketercapaian target-target yang telah disepakati antara legislatif dan eksekutif sesuai dengan peraturan perundangundang.

\section{Analisis Kinerja Keuangan Pemerintah Daerah}

Setiap Pemerintah Daerah untuk mengukur Kinerja Keuangan Daerahnya menggunakan beberapa Rasio Kinerja Keuangan Daerah yang antara lain:

\section{Rasio Derajat Desentralisasi}

Rasio Derajat Desentralisasi dihitung berdasarkan perbandingan antara jumlah Pendapatan Asli Daerah (PAD) dengan Total Pendapatan Daerah. Rasio ini menunjukkan derajat kontribusi PAD terhadap Total Pendapatan Daerah. Semakin tinggi kontribusi PAD maka semakin tinggi kemambuan pemerintah daerah dalam penyelen: desentralisasi. Derajat Desentralisasi, khı komponen PAD dibandingkan dengan

Pendapatan Daerah

Rumus untuk Rasio Desentralisasi sebagai berikut:

$$
\text { sentraliasi }=\frac{\text { Pendapatan.Asli Daerah }}{\text { Total pendapatan Daerah }} \text { 100\% }
$$

\section{Rasio Kemandirian Keuangan Daerah}

Rasio Kemandirian Keuangan Daerah (RKKD) menunjukkan tingkat kemampuan suatu daerah dalam membiayai sendiri kegiatan pemerintah, pembangunan dan pelayanan kepada masyarakat yang telah membayar pajak dan retribusi sebagai sumber pendapatan yang diperlukan daerah.

Rumus untuk Rasio Kemandirian Keuangan daerah sebagai berikut:

$$
\text { Rasio Kemandirian Keuangan Daerah }=\frac{\text { PAD }}{\text { Pendapatan Transf }}
$$

\section{Rasio Efektivitas PAD}

Rasio Efektivitas PAD menggambarkan kemampuan pemerintah daerah dalam merealisasikan PAD yang direncanakan dibandingkan dengan target yang ditetapkan berdasarkan potensi riil daerah. Semakin tinggi Rasio Efektivitas PAD, maka semakin baik kinerja pemerintah daerah.

\section{Rasio Efesiensi Keuangan Daerah}

Rasio Efisiensi Keuangan Daerah (REKD) menggambarkan perbandingan antara besarnya biaya yang dikeluarkan untuk memperoleh pendapatan 
dengan realisasi pendapatan yang diterima. Kinerja Keuangan Pemerintahan Daerah dalam melakukan pemungutan pendapatan dikategorikan efisien apabila Rasio yang dicapai kurang dari 1 (satu) atau di bawah 100\%. Semakin kecil Rasio Efisiensi Keuangan Daerah berarti Kinerja Keuangan Pemerintah Daerah semakin baik.

\section{Rasio Keserasian}

(Rasio Keserasian menggambarkan bagaimana pemerintah daerah memprioritaskan alokasi dananya pada Belanja Operasi dan Belanja Modal secara optimal. Semakin tinggi persentase dana yang dialokasikan untuk Belanja Operasi berarti persentase Belanja Modal yang digunakan untuk menyediakan sarana prasarana ekonomi masyarakat cenderung semakin kecil.

\section{Penelitian Terdahulu}

1. Wijaya (2012) di Kota Surakarta dan Yogyakarta pada tahun 2009-2010 penelitian ini bertujuan untuk mengetahui tingkat kinerja keuangan Pemerintah Kota Surakarta dan Pemerintah Kota Yogyakarta dilihat dari Rasio pendapatan daerah APBD tahun 2009-2010 menggunakan Rasio kemandirian, Rasio efektifitas dan efisiensi, Rasio keserasian dan Rasio pertumbuhan.

2. Yoananda (2012) di kabupatn Surakarta tujuan penelitian ini adalah untuk mengetahui tingkat perkembangan kinerja Pemerintah Surakarta menggunakan Rasio Likuiditas, Rasio Solvabilitas dan Rasio Utang.

3. Adhiantoko (2013) di kabupaten Blora pada tahun 2007-2011 yang diteliti oleh penelitian ini bertujuan untuk menganilisis Kinerja Keuangan DPPKAD Kabupaten Blora tahun 2007-2011 dilihat dari Rasio Derajat Desentralisasi Fiskal, Rasio Kemandirian Keuangan Daerah Rasio Efektivitas PAD, Rasio Efisiensi Keuangan Daerah dan Rasio Keserasian.

4. Idayati (2016) di kabupatn Flores Timur yang diteliti penelitian ini bertujuan untuk menilai Kinerja Keuangan Pemerintah Daerah Kabupaten Flores Timur dengan menggunakan analisis Rasio Keuangan terhadap Anggaran Pendapatan dan Belanja Daerah Kabupaten Flores Timur tahun anggaran 2012-2014.

5. Novrianti (2016) di kabupaten Dharmasraya pada tahun tujuan dari penelitian ini yaitu untuk mengetahui kinerja keuangan Pemerintah Daerah Kabupaten Dharmasraya berdasarkan Rasio kemandirian keuangan daerah, Rasio efektifitas dan efisiensi pendapatan asli daerah, Rasio aktivitas, dan Rasio efesiensi belanja.

\section{Kerangka Pemikiran}

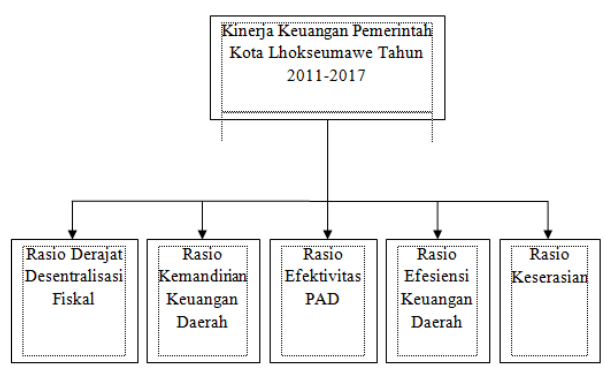

Gambar 1

\section{METODE PENELITIAN \\ Objek dan Lokasi Penelitian}

Dalam penelitian ini yang menjadi objek penelitian adalah kinerja keuangan Pemerintah Kota Lhokseumawe. Sedangkan lokasi untuk mendapatkan data penelitian adalah Kantor BPKD (Badan Pengelolaan keuangan Daerah) Kota Lhokseumawe jalan Merdeka No. 145 Lhokseumawe.

\section{Jenis dan Sumber Data}

Jenis data yg digunakan dalam penelitian ini adalah data kuantitatif. Data kuantitatif adalah data yg berbentuk angka-angka yg dapat diukur dengan satuan hitung. Data kuantitatif dalam penelitian ini adalah Laporan Realisasi Anggaran, Pemerintah Kota Lhokseumawe Tahun 2011-2016.

Sumber data dalam penelitian ini merupakan Data sekunder. Sumber data sekunder merupakan sumber data penelitian yg diperoleh secara tidak langsung melalui media perantara. Sumber data diperoleh dari BPKD (Badan Pengelolaan keuangan Daerah) Kota Lhokseumawe.

\section{Teknik Pengumpulan Data}

Teknik Pengumpulan data yang dilakukan dalam penelitian ini dengan menggunakan metode dokumentasi yaitu pencarian data mengumpulkan data dengan cara mempelajari catatan-catatan dan dokumen-dokumen yang ada. Data dikumpulkan dari DPKAD Kota Lhokseumawe. Data dokumen berupa Laporan Realisasi Anggaran Kota Lhokseumawe Tahun 2011-2016.

\section{PEMBAHASAN \\ Rasio Desentraliasai}

Tabel 1.1

Perhitungan Rasio Derajat Desentralisasi KotaLhokseumawe Tahun Anggaran 2011-2016

\begin{tabular}{|c|c|c|c|c|}
\hline $\begin{array}{c}\text { Tahun } \\
\text { Anggaran }\end{array}$ & $\begin{array}{c}\text { Pendapatan Asli } \\
\text { Daerah (Rp) }\end{array}$ & $\begin{array}{c}\text { Total Pendapatan } \\
\text { Daerah (Rp) }\end{array}$ & $\begin{array}{c}\text { Derajat } \\
\text { Desesntra } \\
\text { lisasi (\%) }\end{array}$ & $\begin{array}{c}\text { Kemampuan } \\
\text { Keuangan }\end{array}$ \\
\hline 2011 & $28.602 .050 .297,21$ & $520.729 .023 .712,21$ & 5,49 & $\begin{array}{c}\text { Sangat } \\
\text { Kurang }\end{array}$ \\
& & & & \\
\hline
\end{tabular}




\begin{tabular}{|c|c|c|c|c|}
\hline 2012 & $28.230 .886 .878,38$ & $582.615 .583 .256,10$ & 4,85 & $\begin{array}{c}\text { Sang } \\
\text { Kur }\end{array}$ \\
\hline 2013 & $36.213 .933 .082,49$ & $643.373 .365 .018,25$ & 5,63 & $\begin{array}{c}\text { San } \\
\text { Kur }\end{array}$ \\
\hline 2014 & $48.730 .219 .320,12$ & $768.270 .271 .382,74$ & 6,34 & $\begin{array}{c}\text { San } \\
\text { Kur }\end{array}$ \\
& & & & \\
\hline 2015 & $56.560 .454 .282,49$ & $835.809 .796 .431,35$ & 6,76 & $\begin{array}{c}\text { San } \\
\text { Kur }\end{array}$ \\
\hline 2016 & $56.348 .631 .473,02$ & $908.888 .389 .623,51$ & 6,20 & $\begin{array}{c}\text { San } \\
\text { Kur }\end{array}$ \\
& & & & \\
\hline
\end{tabular}

Sumber Data : DPKD Kota Lhokseumawe (diolah 2016).

Menurut uraian dan perhitungan pada tabel 1.1 dapat dilihat dan disimpulkan bahwa Rasio Derajat Desentralisasi selama tahun 2011-2016 pada Pemerintah Kota Lhokseumawe masih sangat kurang karena masih berada di skala interval 00,00-10,00\%. Hal ini menunjukan bahwa PAD Pemerintah Kota Lhokseumawe belum mampu untuk membiayai pembangunan daerah karena PAD Kota Lhokseumawe relatif kecil dibandingkan dengan Pendapatan Daerah Kota Lhokseumawe. Hal ini juga disebabkan karena kurangnya kesadaran masyarakat Kota Lhokseumawe untuk membayar pajak dan retribusi daerah lainnya yang merupakan sumber pendapatan PAD sehingga Pemerintah Kota Lhokseumawe masih menggunakan bantuan dari pemerintah pusat untuk membangun daerahnya. Oleh sebab itu kedepannya diharapkan Pemerintah Kota Lhokseumawe dapat berupaya untuk meningkatkan PAD dengan menggembangkan dan memanfaatkan potensi-potensi yang ada dan menggali potensipotensi yang baru.

Rata-rata rasio derajat desentralisasi selama 7 tahun adalah 6,03\%, apabila dibandingkan dengan rasio derajat desentralisasi kabupaten blora sebesar 6,57\%, kabupaten Aceh timur sebesar 2,65\% dan kota yogyakarta sebesar $27,35 \%$. Hal ini menujukan kota Lhokseumawe jika dilihat dari rasio derajat desentralisasi masih sangat kurang karena pemerintah kota Lhokseumawe belum mampu untuk menyelanggarakan desentralisasi dengan mengoptimalkan potensi daerah yang ada.

Pada Penelitian yang dilakukan Adhiantoko (2013) Kinerja Keuangan Kabupaten Blora pada tahun 2007-2011 jika dilihat dari Rasio Desentralisasi masih sangat kurang karena rata-rata rasionya sebesar $6,57 \%$. Hal tersebut kurang lebih sama dengan apa yang terjadi di Kota Lhokseumawe dimana rata-rata kinerja keuangannya sebesar $6,03 \%$ yang tergolong sangat kurang. Menurutnya hal ini terjadi karena ketidakmampuan pemerintah daerah untuk menggali potensi-potensi yang ada. Begitupun yang terjadi di Kota Lhokseumawe dimana peneliti menyimpulkan ketidakmampuan pemerintah daerah untuk menggali potensi-potensi yang ada guna meningkatkan PAD, menyebabkan kinerja keuangan pemerintah daerah
Kota Lhokseumawe dilihat dari Rasio Derajat pesentralisasi masih tergolong sangat kurang.

Rasio Kemandirian Keuangan Daerah

Tabel 1

Perhitungan Rasio Kemandirian keuangan Daerah Kota Lhokseumawe Tahun Anggaran 2011-2016

\begin{tabular}{|c|c|c|c|c|}
\hline $\begin{array}{l}\text { Tahun } \\
\text { Anggaran }\end{array}$ & $\begin{array}{l}\text { Pendapatan Asli } \\
\text { Daerah (Rp) }\end{array}$ & $\begin{array}{c}\text { Pendapatan } \\
\text { Transfer (Rp) }\end{array}$ & $\begin{array}{c}\text { Rasio } \\
\text { Kemandirian } \\
\text { Keuangan } \\
\text { Daerah }(\%)\end{array}$ & $\begin{array}{l}\text { Pola } \\
\text { Hubunga } \\
\mathrm{n}\end{array}$ \\
\hline 2011 & $28.602 .050 .297,21$ & $\begin{array}{c}427.637 .314 .038, \\
00\end{array}$ & 6,68 & Instruktif \\
\hline 2012 & $28.230 .886 .878,38$ & $\begin{array}{c}\text { 496.724.974.727, } \\
00\end{array}$ & 5,68 & Instruktif \\
\hline 2013 & $36.213 .933 .082,49$ & $\begin{array}{c}550.942 .083 .884 \\
00\end{array}$ & 6.57 & Instruktif \\
\hline 2014 & $48.730 .219 .320,12$ & $\begin{array}{c}565.796 .575 .395 \\
00\end{array}$ & 8,61 & Instruktif \\
\hline 2015 & $56.560 .454 .282,49$ & $\begin{array}{c}610.875 .498 .509, \\
00\end{array}$ & 9,26 & Instruktif \\
\hline 2016 & $56.348 .631 .473,02$ & $\begin{array}{c}688.355 .157 .426 \\
00\end{array}$ & 8,18 & Instruktif \\
\hline
\end{tabular}

Sumber Data : DPKD Kota Lhokseumawe (diolah 2016)

Menurut uraian di atas dapat disimpulkan bahwa Rasio Kemandirian Keuangan Daerah selama tujuh tahun pada Pemerintah Kota Lhokseumawe memiliki rata-rata kemandiriannya masih tergolong rendah dan dalam kategori kemampuan keuangan kurang dengan pola hubungan Instruktif yaitu peranan pemerintah pusat masih sangat dominan dibandingkan pemerintah daerah, ini dapat dilihat dari Rasio Kemandirian Keuangan Daerah masih tergolong dalam interval 0\% - 25\%. Rasio Kemandirian yang masih rendah mengakibatkan kemampuan keuangan daerah Kota Lhokseumawe dalam membiayai pelaksanaan pemerintahan dan pembangunan daerah masih sangat tergantug bantuan dari pemerintah pusat.

Rata rasio derajat kemadirian kota Lhokseumawe selama 7 tahun adalah 7,82\%, apabila dibandingkan dengan rasio kemandirian kabupaten kota bogor sebesar 31,89\%, kabupaten Aceh timur sebesar 4,25\% dan kota yogyakarta sebesar 39,87\%. Hal ini menujukan kota Lhokseumawe jika dilihat dari rasio kemandirian masih sangat rendah sekali karena tingkat ketergantungan daerah terhadap sumber dana ekstern masih sangat tinggi.

Pada Penelitian yang dilakukan Novrianti (2016) Kinerja Keuangan Kabupaten Dharmasraya pada tahun 2015. Rata-rata rasionya sebesar $7,70 \%$. Hal ini juga terjadi di Pemerintah Kota Lhokseumawe dimana rata-rata rasionya $7,82 \%$ yang tergolong instruktif. Menurutnya penyebab dari buruknya kinerja keuangan kedua daerah ini hampir sama, hal ini terjadi karena masih besarnya ketergantungan pemerintah daerah Kota Lhokseumawe kepada 
pemerintah Pusat untuk mengolak potensi yang ada guna menaikan PAD.

Rasio Efektifitas PAD

Tabel 2

Perhitungan Rasio Efektivitas PAD KotaLhokseumawe Tahun Anggaran 2011-2016

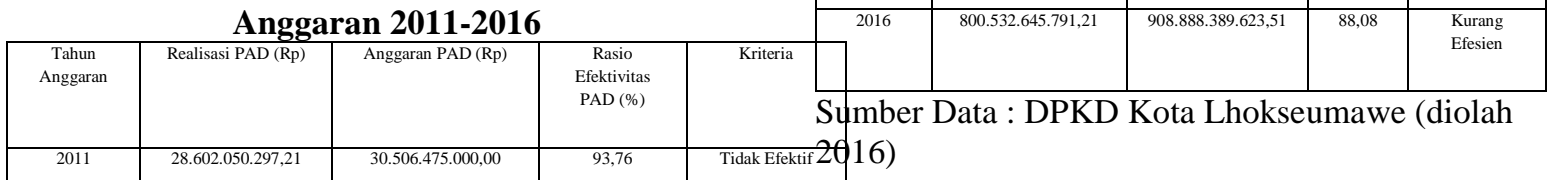

\begin{tabular}{|c|c|c|c|c|}
\hline 2011 & $28.602 .050 .297,21$ & $30.506 .475 .000,00$ & 93,76 & Tidak Efektif \\
\hline 2012 & $28.230 .886 .878,38$ & $35.100 .405 .000,00$ & 80,43 & Tidak Efektif \\
\hline 2013 & $36.213 .933 .082,49$ & $38.350 .390 .000,00$ & 94,43 & Tidak Efektif \\
\hline 2014 & $48.730 .219 .320,12$ & $49.305 .773 .500,00$ & 98,83 & Tidak Efektif \\
\hline 2015 & $56.560 .454 .282,49$ & $67.314 .758 .015,00$ & 84,02 & Tidak Efektif \\
\hline 2016 & $48.730 .219 .320,12$ & $66.754 .367 .843,00$ & 84,41 & Tidak Efektif \\
& & & & \\
\hline
\end{tabular}

Sumber Data : DPKD Kota Lhokseumawe (diolah 2016).

Menurut uraian dan hasil perhitungan pada tabel 1.3 diatas Efektivitas Kinerja Keuangan Kota Lhokseumawe tidak Efektif karena rata-rata efektivitasnya memperoleh nilai kurang dari $100 \%$ yaitu 90,55\% jika dibandingkan dengan kota Bogor sebesar $111,00 \%$ dan kota Yogyakarta sebesar $107,19 \%$. Hal ini disebabkan karena penerimaan dari sektor pajak dan retribusi daerah kurang dari yang dianggarkan sebelumnya. Pemerintah Kota Lhokseumawe juga dapat dikatakan memiliki kinerja yang kurang baik dalam hal merealisasikan PAD yang telah direncanakan.

Pada Penelitian yang dilakukan Novrianti (2016) Kinerja Keuangan Kabupaten Dharmasraya pada tahun 2015. Rata-rata rasionya sebesar $7.70 \%$. Hal ini juga terjadi di Pemerintah Kota Lhokseumawe dimana rata-rata rasionya $90,55 \%$ yang tergolong kurang efektif. Menurutnya penyebab dari buruknya kinerja keuangan kedua daerah ini hampir sama, hal ini terjadi karena karena masih banyaknya masyarakat yang belum patuh dalam membayar pajak, sehingga pendapatan dari pihak masih kecil dan belum sesuai dengan target.

\section{Rasio Efesiensi Keuangan Daerah}

Tabel 3

Perhitungan Rasio Efesiensi Keuangan Daerah Kota Lhokseumawe Tahun Anggaran 2011-2016

\begin{tabular}{|c|c|c|c|c|}
\hline Tahun & Realisasi Belanja & Realisasi & Rasio & Kriteria \\
Anggaran & Dearah (Rp) & Pendapatan Daerah & Efesiens & \\
& & (Rp) & i & \\
& & & Keuanga & \\
& & & \\
& & Daerah & \\
& & & $(\%)$ & \\
& & & & \\
\hline
\end{tabular}

Rata-rata Efisiensi Keuangan Daerah Kota Lhokseumawe yang tergolong masih Kurang Efisien karena rata-rata rasionya 96,59\% jika dibandingkan dengan kota Yogyakarta sebesar 91,69\% dan kabupaten Dharmayasa sebesar 94,28\%. Hal diakibatkan karena total belanja daerahnya masih lepih besar daripada pendapatan daerahnya terutama pada tahun 2011 dan 2015. Meskipun pada tahun 2012, 2013 dan 2014 tersebut Pemerintah Kota Lhokseumawe sudah dapat menekan belanjanya daripada yang dianggarkan sebelumnya namun jumlah pendapatan yang diperolehnya masih sedikit jumlahnya bila dibandingkan dengan belanja daerahnya. Sehingga dapat dikatakan kinerja Pemerintah Kota Lhokseumawe dalam hal ini masih buruk karena belum dapat menekan jumlah belanja daerahnya. Untuk kedepannya diharapkan Pemerintah Kota Lhokseumawe dapat meminimalisir jumlah belanjanya dengan disesuaikan pendapatannya. Sehingga kedepannya dapat terjadi peningkatan efisiensi belanja daerah.

Pada Penelitian yang dilakukan Ardhiankoto (2013) Kinerja Keuangan Kabupaten Blora pada tahun 2007-2011. Rata-rata rasionya sebesar 99,61\%. Hal ini juga terjadi di Pemerintah Kota Lhokseumawe dimana rata-rata rasionya $96,59 \%$ yang tergolong kurang efesien. Menurutnya penyebab dari buruknya kinerja keuangan kedua daerah ini hampir sama, hal ini terjadi karena karena masih besarnya realisasi belanja daerah dibandingan pendapatan daerah yang diterima.

\section{Rasio Keserasian}

Tabel 4

Perhitungan Rasio Keserasian Kota Lhokseumawe Tahun Anggaran 2011-2016 (Belanja Operasi)

\begin{tabular}{|c|c|c|c|}
\hline $\begin{array}{c}\text { Tahun } \\
\text { Anggaran }\end{array}$ & $\begin{array}{c}\text { Total Belanja Operasi } \\
(\mathrm{Rp})\end{array}$ & Total Belanja Daerah (Rp) & $\begin{array}{c}\text { Rasio Belanja Operasi } \\
(\%)\end{array}$ \\
\hline 2011 & $311.944 .636 .087,00$ & $521.424 .477 .433,00$ & 59,83 \\
\hline 2012 & $343.660 .915 .866,00$ & $527.642 .520 .110,00$ & 65,13 \\
\hline 2013 & $385.666 .850 .834,00$ & $623.996 .881 .573,00$ & 61,80 \\
\hline 2014 & $406.641 .590 .656,00$ & $727.480 .904 .420,00$ & 55,89 \\
\hline
\end{tabular}




\begin{tabular}{|c|c|c|c|}
\hline 2015 & $410.895 .811 .476,00$ & $897.070 .194 .380,00$ & 45,80 \\
\hline 2016 & $546.193 .806 .303,21$ & $800.532 .645 .791,21$ & 68,22 \\
\hline
\end{tabular}

Sumber Data : DPKD Kota Lhokseumawe (diolah 2016)

Tabel 5

Perhitungan Rasio Keserasian Kota Lhokseumawe Tahun Anggaran 2011-2016 (Belanja Modal)

\begin{tabular}{|c|c|c|c|}
\hline $\begin{array}{c}\text { Tahun } \\
\text { Anggaran }\end{array}$ & $\begin{array}{c}\text { Total Belanja Modal } \\
(\mathrm{Rp})\end{array}$ & Total Belanja Daerah (Rp) & $\begin{array}{c}\text { Rasio Belanja Modal } \\
(\%)\end{array}$ \\
\hline 2011 & $107.248 .438 .920,00$ & $521.424 .477 .433,00$ & 20,56 \\
\hline 2012 & $107.183 .128 .985,00$ & $527.642 .520 .110,00$ & 20,31 \\
\hline 2013 & $119.231 .217 .739,00$ & $623.996 .881 .573,00$ & 19,11 \\
\hline 2014 & $167.464 .463 .352,00$ & $727.480 .904 .420,00$ & 23,02 \\
\hline 2015 & 223.021 .063 .652 .00 & $897.070 .194 .380,00$ & 24,86 \\
\hline 2016 & $235.985 .010 .488,00$ & $800.532 .645 .791,21$ & 29,48 \\
\hline
\end{tabular}

Sumber Data : DPKD Kota Lhokseumawe (diolah 2016)

Menurut uraian dan perhitungan di atas bahwa sebagian besar dana yang dimiliki Pemerintah Kota Lhokseumawe masih diprioritaskan untuk kebutuhan belanja operasi sehingga rasio belanja modal relatif kecil. Ini dapat dibuktikan dari rata-rata rasio belanja operasi yang masih besar dibandingkan dengan rata-rata rasio belanja modal. Besarnya alokasi dana untuk belanja operasi terutama dikarenakan besarnya dinas-dinas otonomi dan belanja pegawai untuk gaji PNS. Dengan ini dapat menunjukkan bahwa Pemerintah Kota Lhokseumawe yang lebih mementingkan pada pengeluaran-pengeluaran rutin untuk pemenuhan aktivitas Pemerintahan dan belum memperhatikan pembangunan daerah.

Pada penelitian yang dilakukan oleh Ardhiantoko (2013) dijelaskan bahwa kinerja keuangan Pemerintah Kabupaten Blora jika dilihat dari Rasio Keserasian masih kurang stabil Karena selalu terjadi kenaikan maupun penurunan di tiap-tiap periode. Hal tersebut hampir sama apa yang terjadi pada penelitian ini dimana Kinerja Keuangan Pemerintah Kota Lhokseumawe jika dilihat dari Rasio Keserasian masih tidak stabil.

\section{PENUTUP}

\section{Kesimpulan}

Berdasarkan analisis yang telah peneliti teliti, maka dapat ditarik kesimpulan sebagai berikut :

1. Kinerja Keuangan Pemerintah Kota Lhokseumawe jika dilihat dari Rasio Desentralisasi Fiskal dapat di kategorikan sangat kurang, karena masih berada dalam skala dibawah $10,00 \%$.
2. Kinerja Keuangan Pemerintah Kota Lhokseumawe jika dilihat dari Rasio Kemadirian Keuangan Daerah masih tergolong sangat rendah dan pola hubungannya termasuk dalam pola hubungan instruktif, karena masih tergolong dalam interval 0-25\%.

3. Kinerja Keuangan Pemerintah Kota Lhokseumawe jika dilihat dari Rasio Efektivitas PAD tahun 2011-2015 tidak efektif karena masih memperoleh nilai kurang dari $100 \%$.

4. Kinerja Keuangan Pemerintah Kota Lhokseumawe jika dilihat dari Rasio Efesiensi Keuangan Daerah tahun 20112015 kurang efesien karena rata-rata rasionya adalah 99,33\%, yang disebabkan oleh adanya selisih yang cukup besar antara pendapatan dengan belanja Kota Lhokseumawe.

5. Kinerja Keuangan Pemerintah Kota Lhokseumawe jika dilihat dari Rasio Keserasian adalah belum stabil dari tahun ketahun. Pengeluaran belanja operasi lebih besar dari belanja modal. Besarnya belanja operasi rata-rata sebesar 84,55\%, hal ini disebabkan oleh besarnya belanja pegawai karena penambahan jumlah pegawai negeri sipil dan dinas dinas terbaru. Untuk belanja modal rata-rata sebesar $12,99 \%$ sehingga dapat dikatakan pemerintah Kota Lhokseumawe masih kurang memperhatikan pembangunan daerah.

\section{Saran}

Berdasarkan hasil pembahasan dan kesimpulan Analisis Kinerja keuangan Kota Lhokseumawe tahun 2011-2016, adapun saran-sarannya adalah sebagai berikut:

1. Penelitian selanjutnya dapat menggunakan objek yang lain, tidak hanya pada pemerintah Kota Lhokseumawe, tetapi juga pemerintah Aceh yang lebih besar populasinya atau juga dapat membandingkan pemerintah satu dengan pemerintah lainnya.

2. Menambahkan beberapa variabel lain yang berhubungan dengan kinerja keuangan pemerintah daerah untuk melengkapi variabel yang ada.

3. Periode penelitian dapat diperluas bukan hanya selama tujuh tahun, tetapi lebih dari tujuh tahun atau priode penelitian dapat dibuat tahun terbaru.

\section{KEPUSTAKAAN}


Adhiantoko, Hony. (2013). Analisis Kinerja Keuangan Kabupaten Blora (Studi kasus pada Dinas Pendapatan Pengelolaan Keuangan dan Aset Daerah Kabupaten Blora Tahun 2007-2011)'. Skripsi Fakultas Ekonomi Universitas Negeri Yogyakarta.

Aulia, Zikri (2016) Analisis kinerja keuangam pemerintah daerah kabupaten Aceh Timur. Skripsi Fakultas Ekonomi Universitas Sumatera utara. Medan.

Giligan, Thomas W and Matsusaka, John G. 2001. Fiscal Policy, Legislature Size, and Political Parties: Evidence from State and Local Governments in the First Half of the 20th Century. National Tax journal. Vol. 54: $57-82$

Halim, Abdul. (2007). Akuntansi Sektor Publik: Akuntansi Keuangan Daerah. Jakarta : Salemba Empat.

Halim, Abdul. (2012). Pengelolaan Keuangan Daerah. Edisi Ketiga. Yogyakarta : UPP STIM YKPN.

Hendro Sumarjo. (2010). “Pengaruh Karakteristik Pemerintah Daerah Terhadap Kinerja Keuangan Pemerintah Daerah." Skripsi Fakultas Ekonomi Universitas Sebelas Maret.

Hindri, Asmoko. 2015. Korelasi Opini Audit BPK atas LKKL dengan Hasil Evaluasi LAKIP K/L. Artikel Anggaran dan Pembendaharaan Badan Pendidikan dan Pelatihan Keuangan Kementrian Keuangan, pp:1-13.

Idayati, Farida (2016) Analisis kinerja keuangam pemerintah kabupaten Flores. Skripsi Fakultas Ekonomi STIESIA. Surabaya.

Indrarti, Nuansa Mega Okky. 2011. Hubungan antara Opini Audit pada Laporan Keuangan Daerah, Pendapatan Asli Daerah (PAD) dan Dana Alokasi Umum (DAU) terhadap Kinerja Keuangan Daerah. Jurnal. Universitas Riau.

Kusumawardani, Media. 2012. Pengaruh Size, Kemakmuran, Ukuran Legislatif,Leverage Terhadap Kinerja Keuangan Pemerintah Daerah di Indonesia. Skripsi. Semarang : Fakultas Ekonomi UNNES.

Mahsun, Mohamad. (2013). 'Pengukuran Kinerja Sektor Publik. Edisi Pertama'. Yogyakarta: BPFE: hal. 25
Mahmudi. (2015). 'Manajemen Kinerja Sektor Publik'. Yogyakarta: Sekolah Tinggi Ilmu Manajemen YKPN hal. 60.

Mardiasmo. (2002). Otonomi dan Manajemen Keuangan Daerah. Yogyakarta: Penerbit Andi.

Mardiasmo. 2009. Akuntansi Sektor Publik. Jogyakarta: Penerbit Andi.

Masdiantini, Putu Riesty. (2016). 'Pengaruh Ukuran Pemerintah Daerah, Kemakmuran, Intergovermental Revenue, Temuan dan Opini Audit BPK pada Kinerja Keuangan'. E-Jurnal Akuntansi Universitas Udayana, di unduh pada 12 Desember 2016.

Minarsih, Ratna Ayu. (2015). 'Pengaruh Size, Wealth, Laverage dan Intergovermental Revenue terhadap Kinerja Keuangan Pemerintah Daerah di Jawa Tengah'. Jurnal Akuntansi Universitas Negeri Semarang.

Mustikarini, Widya Astuti., Fitriasari, Debby. (2012). 'Pengaruh Karakteristik Pemerintah Daerah dan Temuan Audit BPK terhadap Kinerja Pemerintah Daerah Kabupaen/Kota di Indonesia Tahun Anggaran 2007'. Simposium Nasional Akuntansi XV: Banjarmasin.

Nandhya, Marfiana. (2013). Pengaruh Karakteristik Pemerintah Daerah dan Hasil Pemeriksaan Audit BPK Terhadap Kinerja Keuangan Pemerintah Daerah Kabupaten/Kota. Jurnal. Universitas Sebelas Maret, Surakarta.

Novrianti (2016) Analisis kinerja keuangam pemerintah Dearah Kabupaten Dharmasraya tahun 2015. Skripsi Fakultas Ekonomi dan bisnis IAIN. Batusangkar.

Mutiha, Artaingan (2016) Analisis kinerja keuangam pemerintah daerah Kota Bogor tahun anggaran 2010-2014. Skripsi Fakultas Ekonomi Universitas Indonesia. Jakarta.

Peraturan Pemerintah Republik Indonesia Nomor 58 Tahun 2005, tentang Pengelolaan Keuangan Daerah.

Peraturan Pemerintah No. 24 Tahun 2005 tentang Standar Akuntansi Pemerintahan.

Peraturan Pemerintah Nomor 6 Tahun 2006 tentang Pengelolaan Barang Milik Negara/Daerah. 
Retnowati, Reny. (2016). 'Analisis pengaruh Tingkat Kekayaan Daerah, Ukuran Pemerintah Daerah, Laverage dan Intergovernmental Revenue terhadap Kinerja Keuangan Pemerintah Daerah (Studi Empiris pada Pemerintah Daerah/Kota Se-Jawa Tengah 20112013)'. Jurnal Akuntansi Universitas Muhammadiyah Surakarta.

Riduan Tobing dan Nirwana. (2004). Kamus Istilah Akuntansi. Jakarta: Atalya Rileni Sucedo.

Sijabat, Hubert. 2016. Pengaruh Opini, Temuan

Audit, Kemandirian dan Ukuran

Pemerintah Daerah terhadap Kinerja

Penyelenggaraan Pemerintah Provinsi di

Indonesia Tahun 2010-2014. Skripsi.

Universitas Lampung.

Silky Raditya Siregar. (2012). Faktor - Faktor Yang Mempengaruh Pertimbangan Opini Auditor Atas Laporan Keuangan Pemerintah Daerah Istimewa Yogyakarta. Accounting Analysis Journal Universitas Negeri Semarang, 1(2):1-8.

Suhardjanto, Djoko., Yulianingtyas, Rena Rukmita. 2011. 'Pengaruh Karakteristik Pemerintah Daerah terhadap Kepatuhan Pengungkapan Wajib dalam Laporan Keuangan Pemerintah Daerah (Studi Empiris pada Kabupaten/Kota di Indonesia). Jurnal Akuntansi \& Auditing. Volume 8/No.1/November 20011: 1-194.

Sumarjo, Hendro. 2010. Pengaruh Karakteristik Pemerintah Daerah terhadap Kinerja Keuangan Pemerintah Daerah (Studi Empiris pada Pemerintah Daerah Kabupaten/Kota di Indonesia). Skripsi. Universitas Sebelas Maret. Surakarta.

Surepno. 2013. Pengaruh Return On Equity (ROE), Ukuran (Size), dan Kemakmuran (Wealth) Pemerintah Daerah Terhadap Kinerja Keuangan Pemerintah Daerah di Indonesia. Skripsi. Universitas Negeri Semarang.

Syamsuddin dan Damayanti. (2011). Metode Penelitian Pendidikan Bahasa. Bandung: Remaja Rosdakarya.

Undang-Undang Nomor 32 Tahun 2004 tentang Pemerintahan Daerah.

Undang-Undang Nomor 27 Tahun 2009 tentang Majelis Permusyawaratan Rakyat, Dewan Perwakilan Rakyat, Dewan Perwakilan Daerah, dan Dewan Perwakilan Rakyat.
Undang-Undang No. 33 Tahun 2004 tentang perimbangan keuangan antara pemerintah pusat dan daerah.

Wijaya, Agung (2012) Analisis kinerja keuangam pemerintah kota Surakarta dan kota Yogyakarta dilihat dari rasio pendapatan daerah APBD tahun 2009-2010. Skripsi Fakultas Ekonomi Universitas Muhammadiyah. Surakarta.

Wulandari, Anita. (2001). "Kemampuan Keuangan Daerah di Kota Jambi Dalam Melaksanakan Otonomi Daerah.” Jurnal Kebijakan dan Administrasi Publik, Kemampuan Keuangan Daerah (Vol. 5, No. 2). November.

Yoananda, Glennardilla Dea (2012) Analisis kinerja keuangan pemerintah kota Surakarta. Skripsi Fakultas Ekonomi Universitas Sebelas Maret. Surakarta. 
